\title{
Single paternity within broods of the brown crab Cancer pagurus: a highly fecund species with long-term sperm storage
}

\author{
Niall J. McKeown*, Paul W. Shaw \\ School of Biological Sciences, Royal Holloway University of London, Egham TW20 0EX, UK
}

\begin{abstract}
Declining population sizes reported for a number of marine species have emphasised the need for information on mating systems to be incorporated into conservation and management strategies, particularly for exploited species. The brown crab Cancer pagurus L. supports a major fishery; however, many aspects of the species' mating system, such as paternity patterns, are unresolved. In this study, 3 microsatellite loci conferring a high degree of statistical power were used to determine whether broods from 18 ovigerous females collected from the English Channel had been fertilised by multiple males. Despite the capacity of this species for long-term storage of sperm and the suspected potential for females to use sperm from multiple males simultaneously, no evidence of multiple paternity was detected. Hypotheses as to the predominant processes leading to single paternity are discussed. In systems where females exhibit genetic monogamy the effective population size is constrained by the number of females. Such systems may be particularly susceptible to declines if females are removed. This has important implications for management of C. pagurus populations, as fishery data indicate that females are more heavily harvested than males.
\end{abstract}

KEY WORDS: Crustacea $\cdot$ Cancridae $\cdot$ Paternity $\cdot$ Mating system $\cdot$ Sperm competition $\cdot$ Effective population size $\cdot$ Management

\section{INTRODUCTION}

Many marine species have experienced substantial population declines in recent years (Dulvy et al. 2003). For a number of commercially exploited species, such as the Atlantic cod Gadus morhua, declines have occurred in spite of enormous efforts to ensure sustainability through the collection of data pertaining to abundance, distribution, and age-specific metrics of commercial catches (Hutchings 2003). This has highlighted the need to incorporate knowledge of the ecology of target and non-target species into conservation and management strategies (Rowe \& Hutchings 2003). It is increasingly recognised that different mating systems can confer different susceptibilities of populations to certain conservation risks and affect the ability of populations to respond to changing environmental conditions and selection pressures such as fishing (Rowe \& Hutchings 2003). As a result, the number of studies of mating systems among marine species is growing (Mäkinen et al. 2007, Hyde et al. 2008, Rowe et al. 2008), although the available information does not yet reflect the significant effect these systems can have on population sustainability (Rowe \& Hutchings 2003).

The brown crab Cancer pagurus L. (Brachyura, Cancridae) is distributed along northeast Atlantic coastlines from the Lofoten Islands of Norway to Portugal (Christiansen 1969). It is commercially exploited throughout its geographical range with total landings of 46280 t reported for 2005. As is common in the family Cancridae, mating is observed to occur between a soft bodied (recently moulted) female and a male whose exoskeleton is intact (Edwards 1966, 1979, 
Hartnoll 1969). Courtship is prolonged, with pairings of premoult females and intermoult males for periods of 3 to $21 \mathrm{~d}$ prior to female moulting and mating (Edwards 1966). Pairing has been observed to continue for 1 to $12 \mathrm{~d}$ after mating (Edwards 1966). This extended attendance by the male is presumed to represent pre- and postcopulatory mate guarding (Edwards 1979), which is common in species with soft-shelled female mating (Hartnoll 1969). Sperm plugs occluding the vulva and blocking the vagina become visible in the female soon after copulation (Williamson 1904). Sperm are stored in spermathecae pending spawning. The time gap between insemination and spawning is poorly documented and seems highly variable. For larger females, spawning may occur within a few months of insemination; however, it is also common for spawning to be delayed for up to 15 mo (Pearson 1908). Females may use one supply of stored sperm to fertilise multiple batches of eggs, with reports of 3 successive batches of eggs being fertilised without intervening moults (Pearson 1908). Despite extensive research on the fisheries and biology of C. pagurus, many important aspects of the mating system are unknown. In particular, the genetic mating system (i.e. the occurrence of single versus multiple paternity) has not been described.

Multiple paternity within broods has been reported in the brachyuran crabs Chinoecetes opilio (Roy 2003) and Cancer magister (Jensen \& Bentzen 2002; the latter being the closest known phylogenetic relative of Cancer pagurus (Harrison \& Crespi 1999). However, the limited information available on paternity patterns in brachyuran crabs suggests that a single male typically sires all or a very large fraction of eggs in a brood and that multiple paternity is uncommon (Diesel 1989, 1991, Koga et al. 1993, Jensen et al. 1996, Urbani et al. 1998). Due to the limited period of female receptivity, as well as the occurrence of both mate guarding and sperm plugs, it might be predicted that the incidence of multiple mating and paternity in C. pagurus would be low, at least within a single moult (Hartnoll 1969, Edwards 1979). However, if sperm is retained across moults, the capacity of $C$. pagurus for long-term sperm storage presents the opportunity for sperm from multiple copulations or males to be available to the female for fertilisation of subsequent broods.

Behavioural observations, physiology and phylogeny can be inaccurate predictors of realised animal mating systems (Birkhead 2000). Molecular genetic parentage analysis can permit qualitative and quantitative descriptions of paternity patterns and provide new insights into the breeding biology of species where direct observation is difficult. Burfitt (1980) investigated paternity patterns among broods from 6 ovigerous female Cancer pagurus sampled in the
North Sea using variation at an allozyme locus. The study was hampered by the low levels of genetic polymorphism (maximum 3 genotypes) and, although unexpected allele frequencies were detected for one brood, multiple paternity could not be confirmed. In the present study, more powerful microsatellite markers were employed to investigate whether broods of eggs spawned by individual C. pagurus females had been fertilised by multiple males.

\section{MATERIALS AND METHODS}

Sample collection. Ovigerous crabs overwinter without feeding and are rarely caught in traps (Edwards 1979, Howard 1982). However, 18 berried females were captured as part of a beam trawl survey operated by the Centre for Environment, Fisheries and Aquaculture (CEFAS) in the western English Channel. Carapace width was measured to the nearest millimetre. Tissue samples were obtained from each female by stimulating autotomy of a cheliped. Each cheliped was then stored in $95 \%$ ethanol. Fertilised eggs (hereafter referred to as eggs) were brushed off each female and placed in a vial containing $95 \%$ ethanol labelled according to the female from which they were derived. The females were returned to the sea after sampling.

DNA extraction and amplification of microsatellites. Total DNA was isolated from female cheliped muscle tissue using a cetyltrimethyl ammonium bromide (CTAB)-chloroform/isoamyl alcohol method (after Winnepenninckx et al. 1993). DNA was also isolated from 40 individual eggs from each brood. Due to the small amount of tissue available a Chelex ${ }^{\circledR}$ extraction method (modified from Estoup et al. 1996) was used for individual eggs. Individual eggs were transferred by pipette to $0.2 \mu \mathrm{lPCR}$ tubes and incubated at $37^{\circ} \mathrm{C}$ until the ethanol had evaporated. Then $50 \mu \mathrm{l}$ of $5 \%$ chelating resin (Chelex ${ }^{\circledR}$, Bio-Rad) and $3 \mu$ l of Proteinase K $\left(10 \mathrm{mg} \mathrm{ul}^{-1}\right.$ ) were added to each sample. The mixture was incubated at $55^{\circ} \mathrm{C}$ for $3 \mathrm{~h}$ and boiled $\left(100^{\circ} \mathrm{C}\right)$ for $10 \mathrm{~min}$. Samples were then centrifuged at $16060 \times \mathrm{g}$ for $5 \mathrm{~min}$, and the supernatant removed and stored at $-20^{\circ} \mathrm{C}$. As Cancer pagurus is a highly fecund species with 0.5 to 2.9 million eggs produced per female (Edwards 1979, Ungfors 2007), DNA was also extracted from pooled batches of eggs. This pooling strategy permitted the subsequent screening of a greater number of offspring for non-maternal alleles. Briefly, eggs that were floating freely in ethanol were randomly sampled by pipetting $\sim 750 \mu$ lof the ethanol-egg 'slurry' into an Eppendorf microcentrifuge tube. This was then incubated at $37^{\circ} \mathrm{C}$ until all the ethanol had evaporated. DNA extraction from the 'dried' egg pool then followed the same protocol as for the maternal tissue. Each pool 
contained between 300 to 500 eggs and 4 pools were extracted per brood. For the maternal, individual egg and pooled egg samples, PCR was used to amplify 3 previously developed microsatellite loci (Cpag-4, Cpag-5D8 and Cpag-6C4B; McKeown \& Shaw 2008). The loci are unlinked and free from technical artefacts (null alleles) that could confound results (McKeown \& Shaw 2008). PCR amplification conditions and genotyping protocols are described in McKeown \& Shaw (2008). In the case of the pooled eggs, allelograms representing the alleles present at each locus among the pooled eggs were produced.

Paternity analysis. The probability (power) of the loci to detect multiple paternity in a sample of offspring (PrDM) was estimated using the program PrDM v.1 (Neff \& Pitcher 2002), which employs a Monte Carlo simulation incorporating the effects of (1) number of loci, (2) number of alleles per locus, (3) allele frequencies, (4) number of contributing sires and (5) reproductive skew among the sires. Allele numbers and frequencies estimated from genotyping of adults sampled randomly from multiple locations in the English Channel as part of a wide scale study of population genetic structure were used. Results were consistent regardless of the population sample used (or when all populations data were pooled) and so only the results based on data from the nearest geographical sampling site (Start Point: $50^{\circ} 15^{\prime} \mathrm{N}, 03^{\circ} 33^{\prime} \mathrm{W}, \mathrm{n}=133$ ) are described. A conservative model of 2 contributing sires was run for scenarios of 50:50 and 90:10 paternal contributions. As the probability of detecting multiple paternity is also affected by the number of offspring analysed, the simulation was run assuming a range of numbers (10 to 50) of surveyed offspring.

For each locus the maternal genotype was determined directly from DNA extracted from the female's tissue. The minimum number of fathers for each brood was then inferred using 2 methods. The first was a single locus manual assignment approach whereby the minimum number of sires was estimated to be half the number of non-maternal alleles recorded at a locus (based on both individual and pooled egg allele counts), rounded to the next upper integer if the quotient was uneven (Toonen 2004). Multiple paternity, therefore, was concluded if 3 or more non-maternal alleles were detected at any locus among offspring. The second method was a multilocus approach performed using the program GERUD v. 2.0 (Jones 2005). While this is more sophisticated than allele counting as it uses multiple loci simultaneously, it was only applicable to data derived from individuals. Briefly, following the removal of maternal alleles from each offspring genotype, the minimum number of fathers (and their genotypes) siring each brood was inferred using an exhaustive search algorithm.

\section{RESULTS}

Summary statistics for the population sample screened for the 3 microsatellite loci are reported in Table 1. Overall, the set of microsatellites provided considerable power for detecting multiple paternity within broods (Table 2). As expected, the PrDM increased with sample size. A sample of only 40 eggs (equal to the number of individual eggs assayed per brood) was sufficient to obtain a PrDM of 99.9\% under the assumption of equal male contribution and $92.7 \%$ in the case of a 90:10 paternal skew. With a sample size of 50 eggs (less than that assayed via the pooling method) PrDM was 99.8 to $99.9 \%$ for the simulated models of paternal contribution.

For each brood the genotypes of the 40 individual eggs revealed the same allelic combinations (maternal and presumed paternal alleles) as detected in the respective samples of pooled eggs. Allele counts provided no evidence (i.e. $>2$ paternal alleles at any locus) that more than a single male had contributed to any of the 18 broods tested (Table 3 ). The multilocus analysis was compatible with the single-locus analysis for all broods, as it indicated that mating involving a single male and the genotyped mother was sufficient to produce the respective brood genotypes in each case.

Table 1. Cancer pagurus. Allelic diversity $(k)$, observed and expected heterozygosity ( $H_{\mathrm{obs}}$ and $H_{\text {exp }}$, respectively), and probabilities ( $p$-values) of conformance of genotype proportions to Hardy-Weinberg equilibrium (HWE) for 3 microsatellite loci, based on a sample of 133 adults from Start Point $\left(50^{\circ} 15^{\prime} \mathrm{N}, 03^{\circ} 33^{\prime} \mathrm{W}\right)$ analysed as part of a larger population genetic study. $H_{\text {obs }}$ and $H_{\text {exp }}$ were calculated using FSTAT 2.9.3 (Goudet 1995). HWE test was performed in GENEPOP 3.3 (Raymond \& Rousset 1995)

\begin{tabular}{|lrccc|}
\hline Locus & $k$ & $H_{\text {obs }}$ & $H_{\exp }$ & HWE (p) \\
\hline Cpag-4 & 27 & 0.908 & 0.941 & 0.591 \\
Cpag-5D8 & 27 & 0.880 & 0.895 & 0.626 \\
Cpag-6C4B & 6 & 0.683 & 0.681 & 0.495 \\
\hline
\end{tabular}

Table 2. Cancer pagurus. Probability of detecting multiple paternity (PrDM) for the 3 microsatellite loci for a range of egg numbers assayed (n) and assuming broods to be the product of 2 fathers with equal (50:50) or skewed (90:10) contributions. See 'Materials and methods-Paternity analysis' for simulation details

\begin{tabular}{|lll|}
\hline Eggs $(\mathrm{n})$ & $50: 50$ & $90: 10$ \\
\hline 10 & 0.991 & 0.627 \\
20 & 0.998 & 0.861 \\
30 & 0.999 & 0.946 \\
40 & 0.999 & 0.977 \\
50 & 0.999 & 0.998 \\
\hline
\end{tabular}


Table 3. Cancer pagurus. Designated identification (ID), collection date and carapace width of ovigerous females, and different alleles detected within each brood at each locus by genotyping of mothers and offspring. Alleles are designated by length in base pairs. Maternal alleles are in bold

\begin{tabular}{|c|c|c|c|c|c|}
\hline \multirow[t]{2}{*}{ Female ID } & \multirow[t]{2}{*}{ Date collected } & \multirow[t]{2}{*}{ Carapace width (mm) } & \multicolumn{3}{|c|}{ — Alleles - } \\
\hline & & & Cpag-4 & Cpag-5D8 & Cpag-6C4B \\
\hline 1 & 29 March 2006 & 193 & $214, \mathbf{2 1 7}, \mathbf{2 4 4}, 271$ & $186,192, \mathbf{2 0 1}, 234$ & 172,180 \\
\hline 2 & 4 July 2006 & 158 & $208,211,214,247$ & $186,189,195,207$ & $172,176,180$ \\
\hline 3 & 30 March 2006 & 162 & $220, \mathbf{2 2 6}, \mathbf{2 3 8}, 283$ & 186, 189, 207 & 172,176 \\
\hline 4 & 23 March 2006 & 188 & $250, \mathbf{2 5 6}, 277, \mathbf{2 8 6}$ & $159, \mathbf{1 8 0}, \mathbf{1 9 2}, 231$ & $\mathbf{1 7 2}, 176,180$ \\
\hline 5 & 22 March 2006 & 188 & $205, \mathbf{2 0 8}, \mathbf{2 5 3}, 259$ & $\mathbf{1 8 6}, 189,192,195$ & 172,176 \\
\hline 6 & 24 March 2006 & 181 & $208,214,222,235$ & 159, 186, 204 & $172, \mathbf{1 8 0}$ \\
\hline 7 & 12 July 2006 & 159 & $205,250, \mathbf{2 7 1}, 277$ & $\mathbf{1 9 2}, \mathbf{2 2 5}, 234,243$ & 176,180 \\
\hline 8 & 26 March 2006 & 187 & $\mathbf{2 1 4}, 256, \mathbf{2 6 8}, 277$ & $\mathbf{1 8 6}, \mathbf{1 9 2}, 195$ & $168, \mathbf{1 7 2}, \mathbf{1 8 4}$ \\
\hline 9 & 10 July 2006 & 182 & $\mathbf{2 1 7}, 259,271$ & 168, 192, 195, 204 & $164,172,180$ \\
\hline 10 & 14 August 2006 & 185 & $244,268,274$ & $186, \mathbf{1 8 9}, 195$ & $172, \mathbf{1 7 6}$ \\
\hline 11 & 19 June 2006 & 178 & $\mathbf{2 5 0}, 262,271$ & $180,204,207$ & 172,176 \\
\hline 12 & 20 June 2006 & 147 & $247,265,268,277$ & $183, \mathbf{1 9 2}, \mathbf{1 9 5}, 207$ & $172,176,188$ \\
\hline 13 & 25 March 2006 & 187 & $\mathbf{2 1 1}, 214,217,274$ & $183,189,207$ & 172,176 \\
\hline 14 & 25 March 2006 & 186 & $214, \mathbf{2 2 0}, \mathbf{2 6 8}$ & $183,186,204$ & 172,176 \\
\hline 15 & 24 March 2006 & 100 & $\mathbf{2 4 7}, 259,265,274$ & $165, \mathbf{1 8 6}, \mathbf{2 1 0}, 225$ & $168,172,176$ \\
\hline 16 & 7 July 2006 & 177 & $229, \mathbf{2 3 2}, \mathbf{2 3 8}, 277$ & $174,219,222,238$ & $172,176,180$ \\
\hline 17 & 24 March 2006 & 179 & $223,232,238,259$ & $165, \mathbf{1 7 7}, \mathbf{1 8 0}, 186$ & $172,176,180$ \\
\hline 18 & 19 July 2006 & 145 & $229, \mathbf{2 4 4}, 253,283$ & $\mathbf{1 6 8}, 201, \mathbf{2 1 3}, 219$ & $172, \mathbf{1 7 6}$ \\
\hline
\end{tabular}

\section{DISCUSSION}

In this study, paternity patterns within Cancer pagurus broods were assessed by microsatellite analysis of (1) individual eggs and (2) pools of eggs, sampled from each of 18 ovigerous females collected in the English Channel. This approach, combining the resolution of individual egg genotypes and the screening of a large number of eggs for non-maternal alleles, along with properties of the markers employed, conferred a high degree of investigative power. As a result, the failure to detect multiple paternity in any of the 18 broods permits the robust inference of single paternity in this case.

While the detection of a single case of multiple paternity is sufficient to reject genetic monogamy, it is much more difficult to conclusively demonstrate the absence of multiple paternity. Firstly, for any species, the frequency and degree of multiple paternity can vary temporally, spatially, or phenologically (Sainte-Marie et al. 2002, Roy 2003, Gosselin et al. 2005). Substantial variation in the frequency of multiple paternity has been reported among crustaceans: $80 \%$ (of 10 broods) in the porcelain crab Petrolisthes cinctipes (Toonen 2004); $60 \%$ (of 15 broods) in the crayfish Orconectes placidus (Walker et al. 2002); 54.6\% (of 11 broods) in the Norway lobster Nephrops norvegicus (Streiff et al. 2004); and $13 \%$ (of 108 broods) in the American lobster Homarus americanus (Gosselin et al. 2005). In the snow crab Chinoecetes opilio, multiple paternity was not detected in 2 studies $(0 \%$ of 7 broods, Urbani et al.
1998; $0 \%$ of 5 broods, Sainte-Marie et al. 1999), but low rates of multiple paternity were revealed in a larger study (3.8\% of 79 broods, Roy 2003). It cannot be ruled out that a low level of multiple paternity may not have been detected in the present study due to the number of broods screened. However, it can be concluded that even if multiple paternity occurs in Cancer pagurus it is at very low frequencies and single paternity is the predominant system.

The present study extends the prior observations of mating behaviour in Cancer pagurus (Edwards 1966, 1979) by demonstrating realised fertilisation outcomes and can suggest hypotheses for future study. While it is believed that male cancrids are generally polygynous and exhibit female-centred competition (Orensanz \& Gallucci 1988, Orensanz et al. 1995) the range of female mating behaviors have not been fully resolved. Single paternity could indicate that $C$. pagurus females are monandrous. Monandry, at least within a single moult-mate cycle, might be expected given the limited period of female receptivity as well as the reported mate guarding behaviour and occurrence of sperm plugs. Furthermore, the fitness benefits of multiple matings are often less obvious for females than for males (Hosken 1999, Birkhead 2000, Jennions \& Petrie 2000), particularly when females can store enough viable sperm from a single mating to fertilise their eggs for much of their reproductive lifetime (Hosken 1999). When in a soft-shelled receptive state, female C. pagurus are likely to be highly vulnerable to injuries from competing male mates (Diesel 1991), predators, and 
other females. The ability of $C$. pagurus to use stored sperm to fertilise multiple successive egg clutches might benefit the female by reducing the need for additional matings and the required moults.

Despite the vulnerability of soft-shelled females, moulting is necessary for growth, which in turn increases fecundity (Edwards 1979, Ungfors 2007). Although Cancer pagurus individuals are difficult to age, it is likely, based on their sizes (Table 3), that many of the females sampled in this study have undergone multiple moults, with each moult presenting an opportunity for copulation, presumably involving a different male. It is possible that sperm stores are lost during the moulting process, meaning that females may only contain sperm from a single male at any time. The absence of trans-moult sperm retention has been reported in the brachyuran crabs, Chasmagnathus granulata (López Greco et al. 1999) and Aratus pisonii (Hartnoll 1965). However, trans-moult sperm retention has been demonstrated in cancrids (Orensanz et al. 1995), including Cancer magister (Shirley \& McNutt 1989), which, as mentioned, is the closest known relative of C. pagurus (Harrison \& Crespi 1999). Therefore, sperm loss during moulting would seem unlikely to be the main process leading to single paternity here.

Assuming sperm is retained across moults and that additional males add to the spermathecal sperm supply during moults, single paternity could result from a number of potential mechanisms. Fresh sperm from a new mating might fertilise the majority of eggs due to depletion and/or degradation of older stored sperm. Single paternity might also reflect effective female postcopulatory sperm choice or sperm precedence mechanisms. Postcopulatory mechanisms of female sperm choice include sperm dumping, digestion or other forms of sperm sorting (Thiel \& Hinojosa 2003). Sperm precedence mechanisms, resulting from male-male sperm competition, may result in a single male gaining all fertilisations due to either sperm removal or sperm stratification processes (Birkhead \& Hunter 1990). Removal of previously deposited sperm could involve extraction (Waage 1979) or 'flushing out' (e.g. Rubenstein 1989). However, Orensanz et al. (1995) suggest that sperm extraction is unlikely among the Cancridae. Based on published data, sperm precedence appears to be the most likely mechanism of paternity assurance (if any) involved here. As observed for Cancer magister (Jensen et al. 1996), the spermathecae of Cancer pagurus appear to be the 'ventral' type where the vagina and oviduct open into the spermatheca in close proximity to one another. With such a structure, the last male to inseminate the female is expected to have the advantage (last male sperm precedence). Last male sperm precedence due to sperm stratification has been reported in the snow crab where out of a total of 91 females studied, $88 \%$ had mated with multiple males, but only $3.2 \%$ exhibited multiple paternity within their resulting broods (Urbani et al. 1998, Sainte-Marie et al. 1999, Roy 2003).

The predominance of single paternity in Cancer pagurus provides an interesting addition to the ongoing debate as to the evolutionary significance of polyandry and multiple paternity (Jennions \& Petrie 2000). Proposed benefits of polyandry and multiple paternity include: (1) reducing the chances of reproductive failure due to mating with an incompatible male, such as a relative (Zeh \& Zeh 2003); (2) lowering relatedness among offspring and reducing sibling competition (Yasui 1998); and (3) genetic 'bet-hedging' (Jennions \& Petrie 2000), which may be beneficial in unstable environments (Yasui 1998). It is likely that local populations of $C$. pagurus are large and, therefore, naturally buffered against close-kin mating. Furthermore, the long-lived pelagic larvae have the potential for extensive dispersal, which may serve to reduce sibling competition. The large and dispersive populations of $C$. pagurus may therefore result in little selective disadvantage for single paternity.

At the population level, multiple paternity is suggested to increase effective population size (Martinez et al. 2000). Therefore, single paternity species/populations may be more prone to loss of genetic diversity if population sizes are reduced (e.g. by overfishing) than are genetically polyandrous systems. Theoretical results, however, suggest that by increasing variance in male reproductive success, multiple paternity may reduce the effective population size and genetic diversity of the next generation (Hedrick 2005). In situations where females are each fertilised by a single male in a given reproductive cycle, the number of females imposes a strict constraint on the number of males that can breed. Under this type of mating system, a decline in female numbers would result in proportional reductions in effective population size regardless of the number of males. Species like Cancer pagurus may, therefore, be highly susceptible to decline in effective population size (and related loss of genetic diversity) if overfishing of females occurs. In the $C$. pagurus fishery, female landings per unit effort are considerably higher than those for males for most of the year (Bennett 1995), which emphasises the importance of collecting and monitoring sexspecific landings statistics.

This study suggests that single paternity is the norm for Cancer pagurus. Further research should test this by investigating paternity patterns throughout the species range. Analysis of spermathecal content might also elucidate how mating behaviour (polyandry versus monandry) and/or postcopulatory sexual selection shapes paternity patterns in this economically important species. 
Acknowledgements. The authors are indebted to D. Eaton and members of CEFAS personnel for collecting the samples used in this study. We also thank Z. Patrick for laboratory assistance. This research was funded by the Department for Environment, Food and Rural Affairs as part of project MF0230.

\section{LITERATURE CITED}

Bennett DB (1995) Factors in the life history of the edible crab (Cancer pagurus L.) that influence modelling and management. ICES Mar Sci Symp 199:89-98

Birkhead T (2000) Promiscuity: an evolutionary history of sperm competition. Harvard University Press, Cambridge, MA

Birkhead TR, Hunter FM (1990) Mechanisms of sperm competition. Trends Ecol Evol 5:48-52

Burfitt AH (1980) Glucose phosphate isomerase inheritance in Cancer pagurus L. broods as evidence of multiple paternity (Decapoda: Brachyura). Crustaceana 39:306-310

Christiansen ME (1969) Crustacea Decapoda Brachyura. Marine invertebrates of Scandinavia, 2. Universitetsforlaget, Oslo

$>$ Diesel R (1989) Structure and function of the reproductive system of the symbiotic spider crab Inachus phalangium (Decapoda, Majidae): observations on sperm transfer, sperm storage and spawning. J Crustac Biol 9:266-277

Diesel R (1991) Sperm competition and the evolution of mating behaviour in Brachyura, with special reference to spider crabs (Decapoda: Majidae). In: Bauer RG, Martin JW (eds) Crustacean sexual biology. Columbia University Press, New York, p 145-163

Dulvy NK, Sadovy Y, Reynolds JD (2003) Extinction vulnerability in marine populations. Fish Fish 4:25-64

Edwards E (1966) Mating behaviour in the European edible crab (Cancer pagurus L.). Crustaceana 10:23-30

Edwards E (1979) The edible crab and its fishery in British waters. Fishing News Books, Farnham

Estoup A, Largiader CR, Perrot E, Chourrout D (1996) Rapid one-tube DNA extraction for reliable PCR detection of fish polymorphic markers and transgenes. Mol Mar Biol Biotechnol 5:295-298

Gosselin T, Sainte-Marie B, Bernatchez L (2005) Geographic variation of multiple paternity in the American lobster, Homarus americanus. Mol Ecol 14:1517-1525

Goudet J (1995) FSTAT (version 1.2): a computer program to calculate F-statistics. J Hered 86:485-486

Harrison MK, Crespi BJ (1999) Phylogenetics of Cancer crabs (Crustacea: Decapoda: Brachyura). Mol Phylogenet Evol 12:186-199

Hartnoll RG (1969) Mating in Brachyura. Crustaceana 16: 161-181

Hartnoll RG (1965) Notes on the marine grapsid crabs of Jamaica. Proc Linn Soc Lond 176:113-147

Hedrick P (2005) Large variance in reproductive success and $\mathrm{N}_{\mathrm{e}} / \mathrm{N}$ ratio. Evolution 59:1596-1599

Hosken DJ (1999) Sperm displacement in yellow dung flies: a role for females. Trends Ecol Evol 14:251-252

Howard A (1982) The distribution and behaviour of ovigerous edible crabs (Cancer pagurus), and subsequent sampling bias. J Cons Int Explor Mer 40:259-261

Hutchings JA (2003) Update COSEWIC status report on Atlantic cod Gadus morhua in Canada. COSEWIC assessment and status report on the Atlantic cod Gadus morhua in Canada, Committee on the Status of Endangered Wildlife in Canada, Ottawa
Hyde JR, Kimbrell C, Robertson L, Clifford K, Lynn E, Vetter R (2008) Multiple paternity and maintenance of genetic diversity in the live-bearing rockfishes Sebastes spp. Mar Ecol Prog Ser 357:245-253

Jennions MD, Petrie M (2000) Why do females mate multiply? A review of the gentic benefits. Biol Rev Camb Philos Soc $75: 21-64$

Jensen PC, Bentzen P (2002) Multiple paternity of Dungeness crabs (Cancer magister) determined using novel microsatellite markers. 20th Lowell Wakefield Fisheries Symposium (World Meeting No. 000 5935), Juneau, AK

Jensen PC, Orensanz JM, Armstrong DA (1996) Structure of the female reproductive tract in the Dungeness crab (Cancer magister) and implications for the mating system. Biol Bull (Woods Hole) 190:336-349

> Jones AG (2005) GERUD 2.0: a computer program for the reconstruction of parental genotypes from half-sib progeny arrays with known or unknown parents. Mol Ecol Notes 5:708-711

> Koga T, Henmi Y, Murai M (1993) Sperm competition and the assurance of underground copulation in the sand-blubber crab Scopimera globosa (Brachyura: Ocypodidae). J Crustac Biol 13:134-137

López Greco LS, López GC, Rodriguez EM (1999) Morphology of spermathecae in the estuarine crab Chasmagnathus granulata Dana 1851 (Grapsidae, Sesarmine). J Zool 249:490-493

Mäkinen T, Panova M, André C (2007) High levels of multiple paternity in Littorina saxatilis: hedging the bets? J Hered 98:705-711

Martinez JL, Moran P, Perez J, De Gaudemar B, Beall E, Garcia-Vasquez E (2000) Multiple paternity increases effective size of southern Atlantic salmon populations. Mol Ecol 9:293-298

McKeown NJ, Shaw PW (2008) Polymorphic nuclear microsatellite loci for studies of brown crab, Cancer pagurus L. Mol Ecol Notes 8:653-655

Neff BD, Pitcher TE (2002) Assessing the statistical power of genetic analyses to detect multiple mating in fishes. J Fish Biol 61:739-750

> Orensanz JM, Gallucci VF (1988) Comparative study of postlarval life-history schedules in four sympatric species of Cancer (Decapoda: Barchyura: Cancridae). J Crustac Biol 8:187-220

Orensanz JM, Parma AM, Armstrong DA, Armstrong J, Wardrup P (1995) The breeding ecology of Cancer gracilis (Crustacea, Decapoda, Cancridae) and the mating system of cancrid crabs. J Zool 235:411-437

Pearson J (1908) Cancer (the edible crab). Mem Liverpool Mar Bio Comm 16

Raymond M, Rousset F (1995) GENEPOP (version 1.2): population genetics software for exact tests and ecumenicism. J Hered 86:248-249

Rowe S, Hutchings JA (2003) Mating systems and the conservation of commercially exploited marine fish. Trends Ecol Evol 18:567-572

> Rowe S, Hutchings JA, Skjraasen JE, Bezanson L (2008) Morphological and behavioural correlates of reproductive success in Atlantic cod Gadus morhua. Mar Ecol Prog Ser 354:257-265

Roy N (2003) Incidence de la polyandrie chez le crabe des neiges, Chionoecetes opilio (Brachyura, Majidae). MSc thesis, Université du Québec à Rimouski

- Rubenstein DI (1989) Sperm competition in the water strider, Gerris remigis. Anim Behav 38:631-636

> Sainte-Marie B, Urbani N, Sévigny JM, Hazel F, Kuhnlein U (1999) Multiple choice criteria and the dynamics of assor- 
tative mating during the first breeding season of female snow crab Chionoecetes opilio (Brachyura, Majidae). Mar Ecol Prog Ser 181:141-153

Sainte-Marie B, Sévigny JM, Carpenter M (2002) Interannual variability of sperm reserves and fecundity of primiparous females of the snow crab (Chionoecetes opilio) in relation to sex ratio. Can J Fish Aquat Sci 59:1932-1940

Shirley TC, McNutt L (1989) Precocious mating and transmoult sperm retention by female Dungeness crabs. Am Zool 29:131A (Abstract)

Streiff R, Mira S, Castro M, Cancela ML (2004) Multiple paternity in Norway lobster (Nephrops norvegicus L.) assessed with microsatellite markers. Mar Biotechnol 6: 60-66

Thiel M, Hinojosa IA (2003) Mating behaviour of female rock shrimp Rhynchocinetes typus (Decapoda: Caridae): indication for convenience polyandry and cryptic female choice. Behav Ecol Sociobiol 55:113-121

Toonen RJ (2004) Genetic evidence of multiple paternity of broods in the intertidal crab Petrolisthes cinctipes. Mar Ecol Prog Ser 270:259-263

Ungfors A (2007) Sexual maturity of the edible crab (Cancer pagurus) in the Skagerrak and the Kattegat, based on reproductive and morphometric characters. ICES J Mar

Editorial responsibility: Hans Heinrich Janssen, Oldendorf/Luhe, Germany
Sci 64:318-327

Urbani N, Sainte-Marie B, Sévigny JM, Zadorny D, Kuhnlein U (1998) Sperm competition and paternity assurance during the first breeding period of female snow crab (Chionoecetes opilio) (Brachyura: Majidae). Can J Fish Aquat Sci 55:1104-1113

Waage JK (1979) Dual function of the damselfly penis: sperm removal and transfer. Science 203:916-918

> Walker D, Porter BA, Avise JC (2002) Genetic parentage assessment in the crayfish Orconectes placidus, a highfecundity invertebrate with external maternal brood care. Mol Ecol 11:2115-2122

Williamson HC (1904) Contributions to the life-histories of the edible crab (Cancer pagurus) and of other Decapod Crustacea: impregnation, spawning, casting, distribution, rate of growth. Rep Fish Board Scotl 22:100-140

Winnepenninckx B, Backeljau T, DeWachter R (1993) Extraction of high-molecular-weight DNA from molluscs. Trends Genet 9:407

Yasui Y (1998) The 'genetic benefits' of female multiple mating reconsidered. Trends Ecol Evol 13:246-250

Zeh JA, Zeh DW (2003) Toward a new sexual selection paradigm: polyandry, conflict, and incompatibility. Ethology 109:929-950

Submitted: January 17, 2008; Accepted: June 25, 2008

Proofs received from author(s): September 13, 2008 